\title{
JUSTIFICAÇÃO, CONFIABILISMO E VIRTUDE INTELECTUAL
}

Alexandre Meyer Luz*

SÍNTESE - Este ensaio se ocupará de uma noção que debuta muito recentemente no cenário do debate epistemológico contemporâneo, a saber, a noção de virtude intelectual. Vamos discutir, aqui, uma das abordagens da noção de virtude, aquela moldada na forja confiabilista. Receberão destaque especial os trabalhos de Alvin Goldman e Ernest Sosa, nesta ordem. Veremos que "virtude intelectual' será entendida, grosso modo, como uma evolução da noção de 'processo confiável de formação de crenças', evolução motivada por três críticas à teoria confiabilista. Pretendemos mostrar, ainda, que uma destas críticas não é resolvida, exatamente a crítica que ataca um dos pilares do programa confiabilista: a dispensa de crenças de segunda ordem sobre a justificação.

PALAVRAS-CHAVE - Justificação. Confiabilismo. Virtude intelectual.
ABSTRACT - This essay is concerned with a notion that was recently introduced in the contemporary epistemological debate, the notion of an intellectual virtue. We will be discussing one of the approaches to the notion of virtue, that which comes from the reliabilist forge. I will be especially concemed with the works of Alvin Goldman and Ernest Sosa, in that order. We will see that 'intellectual virtue' will be, by and large, understood as the evolution of the notion of 'reliable belief-forming process', an evolution that is prompted by three objections to reliabilist theory. We intend to show that one of those objections is not removed, precisely the one that is aimed at one of the pillars of the reliabilist program: the avoidance of a condition requiring second-order beliefs about justification.

KEY WORDS - Justification. Reliabilism. Intellectual virtue.

\section{0 confiabilismo como alternativa ao internalismo}

O confiabilismo surge no debate epistemológico, no final dos anos setenta, como uma reação às teorias internalistas da justificação. As razões para o rompimento com a tradição internalista podem ser localizadas já no ensaio confiabilista seminal, What is justified belief?, ${ }^{1}$ publicado em 1979. Nesse ensaio, Alvin Goldman - o confiabilista primevo ${ }^{2}$ - já atacava algumas teses centrais do internalismo. Vejamos, por exemplo, a seguinte passagem:

Departamento de Filosofia. Universidade Federal de Sergipe.

GOLDMAN, Alvin I. What is justified belief? In PAPPAS, G. S. (Ed.). Justification and knowledge. Dordrecht: D. Reidel, 1979, pp. 1-23.

Podemos, eventualmente, encontrar intuições que poderiam ser classificadas como confiabilistas em autores anteriores. Nenhum deles, porém, parece ter desenvolvido de modo substancial uma teoria confiabilista da justificação, antes de Goldman (agradeço a Paulo Faria por este ponto).

\begin{tabular}{|l|l|l|l|l|l|} 
VERITAS & Porto Alegre & v. 50 & n. 4 & Dezembro 2005 & p. 191-218
\end{tabular}


[...] Muitas vezes se assume que, sempre que uma pessoa tem uma crença justificada, ela sabe que a crença é justificada e sabe qual é a justificação. Segundo essa visão, uma justificação é um argumento, uma defesa ou um conjunto de razões que podem ser dadas a favor de uma crença. Dessa forma, estuda-se a natureza da crença justificada considerando o que uma pessoa poderia dizer se fosse solicitada a defender ou justificar sua crença. Não faço nenhum desses tipos de pressuposição aqui. Se, quando uma crença é justificada, aquele que crê sabe que ela é justificada, será deixado como questão aberta. Também fica aberta a questão de se, quando a crença é justificada, aquele que crê pode enunciar ou dar uma justificação para ela. Eu nem sequer vou assumir que, quando uma crença é justificada, há alguma coisa "possuída" por aquele que crê, algo que poderia ser chamado de "justificação" .

Pelo menos duas teses centrais do internalismo aparecem aqui sob fogo cerrado. Primeiramente, Goldman dispensa o sujeito conhecedor de qualquer tipo de crença sobre o processo de justificação, mesmo que condicionalmente. ${ }^{4}$ Mais do que isso, ele nega a idéia de que o que confere justificação a uma crença tem que ser imediatamente acessivel $l^{5}$ ao sujeito conhecedor.

O rompimento com estas duas pressuposições é suficiente para caracterizar um rompimento com o internalismo. Como alternativa, Goldman propõe o seu confiabilismo histórico (ou genético), inspirado nas teses seguintes:

(T1) A tarefa do confiabilismo consiste em especificar, em termos não-epistêmicos, quando uma crença é justificada.

(T2) Esta tarefa será cumprida através da descrição - não da prescrição - dos nossos padrões comuns de justificação.

(T3) Uma crença deve ser considerada justificada quando ela é produzida por um ou mais processos que costumam produzir mais verdades do que falsidades (ou seja, quando é produzida por um conjunto de processos confiáveis).

(T4) O sujeito conhecedor é dispensado de qualquer crença de segunda ordem ${ }^{6}$ sobre este processo confiável.

Devemos analisar mais cuidadosamente este resumo do programa confiabilista. Em primeiro lugar, voltemos ao rompimento com o internalismo. Tradicionalmente, um internalista procurará especificar as condições para a justificação em termos do que é, por exemplo, 'claro', 'evidente' ou ‘certo', para o sujeito epistêmico - todos termos epistêmicos. Como (T1) indica, Goldman considera este pressuposto - tipicamente internalista - inadequado. Inspirado pelo espírito do natura-

Id., p. 2

O internalista, em geral, não exige crença atual naquilo que justifica uma crença em questão. Ele exigirá, apenas, que o sujeito conhecedor, por exemplo, seja capaz de acessar aquilo que justifica a crença.

5 Richard Feldman e Earl Conee sustentam que a acessibilidade é apenas uma das alternativas para apresentação da tese internalista. A outra consiste no que é denominado por eles de "mentalismo", que consiste na sugestão de que o que caracteriza uma teoria como internalista é a asserção de que "justificação é determinada inteiramente por fatores mentais ocorrentes" (p. 2). (FELDMAN, R. \& CONEE, E., Internalism defended. American Philosophical Quarterly, Vol. 38, N.1, Janeiro 2001, pp. 1-17)

Crenças de segunda ordem são aquelas crenças que têm como objeto outras crenças. 
lismo epistemológico, ${ }^{7}$ ele pretende apresentar uma concepção de justificação que faça apelo apenas a propriedades naturais, não-epistêmicas. Estas propriedades naturais nos aparecem quando descrevemos os processos de aquisição de crença, os processos e métodos efetivamente utilizados pelos indivíduos para a aquisição de crenças. Isto, por sua vez, nos remete para (T2). Enquanto a tradição internalista, fortemente normativista, pretende apresentar um conjunto de requisitos que prescrevem a situação em que o sujeito epistêmico deve se encontrar para que esteja justificado em relação a uma crença, o confiabilismo introduzirá apenas indiretamente o normativismo na epistemologia.

É (T4), porém, que marca, de modo definitivo, a separação entre internalistas e confiabilistas. Como já mencionamos, o internalista, freqüentemente, define justificação se valendo de outros conceitos epistêmicos ('clareza', 'certeza', 'coerência', etc.). Seguindo uma tradição que remete pelo menos até Descartes, o internalista considera que quando uma crença (ou conjunto de crenças) possui certo tipo de qualidade especial (quando ela é 'clara', 'evidente', 'coerente', etc.), isto se mostra à razão do sujeito epistêmico. No empirismo lockeano, por exemplo, conhecimento "não é outra coisa senão a percepção da conexão e do acordo, ou da oposição e desacordo em quaisquer das nossas idéias". ${ }^{8}$ Para o internalista, seguindo tal intuição, o sujeito epistêmico sempre poderá ter acesso (na terminologia lockeana, percepção) àquilo que, em última análise, justifica uma crença ocorrente. ${ }^{9}$ Mais do que a exigência de que aquilo que justifica a crença seja interno ao sujeito epistêmico (algo que o confiabilista pode aceitar), a característica que une as diversas formas de internalismo é a exigência da acessibilidade. E é esta exigência que (T4) dispensa.

(T3), por sua vez, resume a teoria da justificação confiabilista. Vamos, agora, proceder a uma exposição dessa teoria da justificação, ressaltando os aspectos da sua transformação ao longo de três fases: a primeira versão, aquela que aparece em What is justified belief?; a segunda, a de Epistemology and cognition; $;^{10}$ por fim, aquela que interessa de modo particular à nossa investigação, aquele confiabilismo que incorpora a noção de virtude, em Liaison: Philosophy meets the cognitive and social sciences. ${ }^{11}$

Deve-se cuidar, porém, com uma aproximação entre o projeto goldmaniano e a proposta quineana de naturalização. Goldman, por exemplo, discorda da idéia quineana da absorção da epistemologia pela psicologia, assim como do suposto caráter meramente descritivo da epistemologia. Uma investigação sobre as relações entre o projeto goldmaniano e o naturalismo pode ser encontrada em DUTRA, Luiz H., Normatividade e investigação. Principia - Revista Internacional de Epistemologia, v. 1, n. 1, 1997, pp. 7-55.

LOCKE, John. Ensaio sobre o entendimento humano. Lisboa: Fundação Calouste Gulbenkian, 1999, p. 719. (Livro IV, Cap. I).

9 Uma crença é 'ocorrente' quando ela é dada, efetivamente, para o sujeito epistêmico, num dado instante. Tomemos, porém, a proposição '1734,6 + 789,3 = 2523,9'; você, provavelmente, nunca se ocupou dela anteriormente. Dada sua formação em aritmética, porém, você creria justificadamente no resultado da adição, se dela tivesse se ocupado. Esta crença disposicional está justificada para os que dominam as operações aritméticas. Esta justificação dispensa, certamente, a posse de crença de segunda ordem sobre a crença em questão.

10 GOLDMAN, Alvin. Epistemology and cognition. Cambridge: Harvard University Press, 1986.

11 GOLDMAN, Alvin. Liaisons: philosophy meets the cognitive and social sciences. Cambridge: The MIT Press, 1991. 


\section{Epistemologia e cognição}

O ensaio publicado por Alvin Goldman em 1986, Epistemology and cognition, tem um objetivo ambicioso, enunciado já no início de sua Introdução: "redirecionar e reestruturar o campo da epistemologia". 12 A epistemologia renovada, preocupada tanto com os aspectos individuais quanto com os aspectos sociais do conhecimento, será marcada pela cooperação intensa com as ciências - sem que, com isso, sejam abandonadas as pretensões normativistas tradicionalmente atribuídas à epistemologia. Seguindo o programa já estabelecido em 1979, porém, tais pretensões serão estabelecidas através do apelo à conexão entre nosso "equipamento cognitivo" e a verdade.

O "redirecionamento" dos trabalhos em epistemologia pode ser entendido, pois, num primeiro momento, como um rompimento com a tradição anti-psicologista pósfregeana. A abordagem do conceito de justificação segue, em linhas gerais, o programa anunciado em What is justified belief?, aí incluídos o rompimento com o internalismo e o papel central da noção de confiabilidade. Há, porém, desenvolvimentos que merecem nossa atenção.

A abordagem da justificação no ensaio de 86 (e temos aqui algo de novo, em relação ao ensaio de 79) é elaborada numa perspectiva de um conjunto de regras. Há três razões para a preocupação com a elaboração desta estrutura: primeiramente, a noção de regra permite a explicitação do caráter normativo da justificação, pois "chamar uma crença de justificada implica que ela é uma atitude doxástica apropriada, uma em relação a qual o [sujeito] conhecedor tem autorização ou direito epistêmico". ${ }^{13}$ Em segundo lugar, a estrutura de regras fornece uma estrutura neutra para a classificação de diferentes intuições sobre o conceito de justificação. Em terceiro lugar, a estrutura de regras permite um "paralelo instrutivo entre avaliação epistêmica e avaliação social e oral", o que permite maior clareza na identificação dos problemas e das conseqüências de uma posição assumida.

Estas intuições se materializam na seguinte definição de justificação, em Epistemology and cognition:

(P3) A crença de $\mathrm{S}$ em $\mathrm{p}$ em t é justificada se e somente se

(a) A crença de S em p em t é permitida por um sistema correto de Regras-J, e

(b) Esta permissão não é desqualificada [undermined] pelo estado cognitivo de $\mathrm{S}$, em t.

Acompanhada do seguinte critério para correção de conjuntos de regras:

(ARI) Um sistema R de Regras-J é correto se e somente se

R autoriza certos processos psicológicos (básicos), e a instanciação destes processos resultaria em uma taxa de crenças verdadeiras que atingiria algum limiar elevado previamente especificado (maior do que .50). ${ }^{14}$

Ou seja, se os processos autorizados são confiáveis.

2 GOLDMAN, Alvin. Epistemology and cognition. Cambridge: Harvard University Press, 1986.
Epistemology and cognition, p. 59.

Epistemology and cognition, p. 106. 


\section{Confiabilismo e virtude}

A exposição anterior permitiu ao leitor acompanhar o aumento do grau de sofisticação da teoria confiabilista da justificação, desde a formulação inicial de What is justified belief? até Epistemology and cognition. Agora, no terceiro momento da parte expositiva, acompanharemos a incorporação da noção de virtude à teoria confiabilista.

A utilização da noção de virtude na epistemologia não é, em si, algo original. Aristóteles, como é bem-sabido, utilizou o conceito e a ele dedicou considerável espaço na Ética a Nicômaco. O surgimento da noção no discurso epistemológico contemporâneo, porém, dá-se de um modo bastante distinto, como veremos. ${ }^{15}$

O mérito de ter sido o primeiro epistemólogo contemporâneo a sugerir a utilização da noção de virtude em epistemologia cabe a Ernest Sosa. Em The raft and the pyramid: coherence versus foundations in the theory of knowledge, ${ }^{16} \mathrm{com} 0$ objetivo de superar o debate fundacionismo/coerentismo, Sosa sugere que compreendamos a noção de justificação como algo ligado a virtudes intelectuais, algo ligado "a disposições estáveis para a aquisição de crenças, devido a sua grande contribuição no que diz respeito à obtenção da verdade" ${ }^{17}$ Esta sugestão não será, todavia, desenvolvida em The raft and the pyramid, mas apenas em ensaios posteriores, de um modo intimamente conectado ao confiabilismo. Goldman subscreverá, como veremos, a noção, tal qual formulada por Sosa. Por esta razão, passaremos agora à análise da noção de virtude, como formulada por Ernest Sosa, para, depois, acompanhar sua recepção na obra goldmaniana.

\subsection{Três ataques ao confiabilismo}

Como já indicado, a teoria das virtudes intelectuais surge, no final da década de 70, como uma proposta de superação do suposto impasse das teorias coerentistas e fundacionistas. A efetiva tarefa de transformação da mera sugestão em uma teoria substantiva foi realizada ao longo da década de 80, sendo apresentada em uma versão sofisticada em 1991, em Reliabilism and intellectual virtue e em Intellectual virtue in perspective ${ }^{18}$. Passaremos, agora, a uma reconstrução da noção de virtude ali proposta. Como veremos a seguir, Sosa utilizará a noção de virtude de modo conseqüencialista, relacionando-a intimamente com o confiabilismo.

15 Podemos encontrar, no debate contemporâneo, teorias inspiradas explicitamente na obra aristotélica como, por exemplo, a elaborada por Linda Zagzebski em Virtues of the mind - An inquiry into the nature of virtue and the ethical foundations of knowledge. Cambridge: Cambridge University Press, 1996.

16 Publicado originalmente em FRENCH, UEHLING \& WETTSTEIN, Midwest studies in epistemology, vol. V - Studies in epistemology (Minneapolis: University of Minnesota Press, 1980) e reimpresso em SOSA, Ernest, Knowledge in perspective - Selected essays in epistemology (Cambridge: Cambridge University Press, 1991). Referências ao ensaio serão feitas considerando-se a versão de 1991.

17 In. SOSA, E. Knowledge in perspective: selected essays in epistemology (Knowledge in perspective, doravante). p. 189.

18 Trata-se, respectivamente, do oitavo e do décimo-sexto dos ensaios de Knowledge in perspective. 
O apelo à noção de virtude intelectual tem, para Sosa, dupla função: por um lado, será central para o desenvolvimento de sua teoria do perspectivismo das virtudes; por outro, significa um passo adiante no desenvolvimento do programa confiabilista. Mais particularmente, sob este aspecto, a introdução de tal noção permitirá a superação de três graves problemas para o confiabilismo goldmaniano: o Problema da Generalidade, o Problema da Meta-Incoerência e o Novo Problema do Demônio Maligno, que discutiremos a seguir.

\subsubsection{O problema da generalidade}

O problema da generalidade, percebido inicialmente pelo próprio Goldman, ${ }^{19}$ ataca diretamente o conceito, caro aos confiabilistas, de processo formador de crença. Tomemos, por exemplo, uma crença verdadeira, produzida por um processo de produção de crenças especificado de modo tão restrito a ponto de o número de crenças por ele produzidas ser muito pequeno. Por exemplo, imaginemos uma crença verdadeira produzida por um processo tal que, dentre seus componentes, conte com a presença, na abóbada celeste, de modo visível, do cometa Halley e da lua cheia. ${ }^{20}$ Tal processo deve ser considerado (a despeito de produzir muito mais verdades do que falsidades) como um processo confiável? Se sim, devemos conceder que crenças por ele produzidas estejam justificadas (nos termos do confiabilismo goldmaniano)? Podemos facilmente sustentar que não devemos aceitar tais casos como casos de conhecimento, já que o processo produtor da crença é excessivamente restritivo e, por isso, fornece-nos um número baixo de crenças, um número insuficiente para que a confiabilidade do processo seja avaliada (num extremo, a descrição pode ser tão detalhada que o número total de crenças produzidas pelo processo assim descrito é de apenas uma crença - a versão Caso Único do Problema da Generalidade). E, por outro lado, se a descrição dos processos agrupa modelos muito genéricos, ela acaba por agrupar casos com singularidades importantes - a versão Não-Discriminação do Problema da Generalidade. ${ }^{21}$ Se o modelo geral é aquele denominado de "visão", sem maiores qualificações, agrupamos indevidamente casos em que vemos objetos pequenos à distância, casos em que os vemos sob boa iluminação, etc. Estes casos têm, podemos concordar, graus de confiabilidade muito diferentes.

19 Já em What is justified belief? Goldman observava que "relações de entrada/saída podem ser especificadas muito estreitamente ou muito amplamente, e o grau de generalidade vai, em parte, determinar o grau de confiabilidade. Um tipo de processo poderia ser selecionado de modo tão estreito que teríamos dele apenas uma instância e, daí, o tipo [de processo] seria completamente confiável ou completamente não-confiável." (p. 12)

20 A coincidência de eventos é, no caso em que estamos apresentando, externa. Podemos imaginar, porém, que esta coincidência de eventos se dê como uma coincidência de eventos fisicamente internos ao sujeito conhecedor.

21 Veja Sosa, 1991, p. 182 ss. e também Epistemology and cognition, pp. 49-50. Uma apresentação mais sofisticada do problema pode ser encontrada no ensaio de Richard Feldman, Reliability and justification (The Monist, 68:2, 1985, 159-174). 
O problema fica completo quando consideramos que não temos indicações prévias sobre a descrição que devemos fornecer de um suposto processo formador de crenças; um interlocutor poderia - legitimamente - requerer que o processo fosse descrito de modo extremamente minucioso (já que não sabemos, de saída, o que conta para a confiabilidade do processo), caindo no problema da excessiva especificidade do processo. Um outro interlocutor, mais exigente ainda, poderia considerar que o recorte ainda é muito genérico. E, se não pudermos descrever adequadamente um processo confiável de formação de crenças, parece evidente que uma teoria baseada em tal noção se mostraria inviável.

\subsubsection{O Novo Problema do Demônio Maligno}

O Novo Problema do Demônio Maligno não é, certamente, o problema cartesiano. Como se perceberá, porém, é seu correlato. Imaginemos dois grupos de indivíduos, com faculdades mentais semelhantes. Um grupo é composto, digamos, por seres humanos como nós, vivendo num ambiente como o nosso (vamos conceder que este grupo viva num ambiente tal que suas crenças sobre o mundo externo são, em larga medida, verdadeiras). O segundo grupo é composto por gêmeos do primeiro grupo, mas que vivem num ambiente manipulado por um demônio maligno a la Descartes. Estes indivíduos possuem, podemos imaginar, pelo menos muitos dos mesmos processos formadores de crenças que equipam seus irmãos que vivem no mundo normal. Ao contrário destes, porém, os gêmeos que vivem no mundo manipulado possuem crenças sistematicamente falsas.

A questão logo se estabelece: se os processos de formação de crença são confiáveis para o primeiro grupo, o grupo que está, digamos, na situação normal, por que deveríamos tomar como injustificadas crenças formadas pelos mesmos processos, só que nas condições menos favoráveis impostas pelo demônio? ${ }^{22}$

\subsubsection{O Problema da Meta-Incoerência}

O terceiro problema é o chamado 'problema da Meta-Incoerência'. Vamos supor que uma pessoa crê em $p$ (que o Presidente está em Nova Iorque, por exemplo), que $p$ é derivada de uma dada habilidade de clarividência desta pessoa, que esta habilidade de clarividência é, de fato, confiável (ou seja, tende a produzir mais crenças verdadeiras do que crenças falsas) e que "(a) tal pessoa tem muitas evidências ordinárias contra ela [a habilidade de clarividência], e nenhuma em seu favor; ou (b) tal pessoa tem muitas evidências contra sua posse de tal poder de

22 Este problema é proposto por Keith Lehrer e Stewart Cohen em Justification, truth and coherence, Synthese, 55 (1983): 191-207. apud. SOSA, Ernest. Knowledge in perspective - selected essays in epistemology (Cambridge: Cambridge University Press, 1991, cap. 8, p. 132. Sosa, que é um externalista, aceita que tal problema traz complicações para certas versões do externalismo, como a teoria confiabilista de A. Goldman. Para superar este (assim como o próximo) problema, Sosa proporá sua teoria da virtude intelectual. O próprio Goldman, posteriormente, se aproximará explicitamente de uma abordagem baseada na noção de virtude intelectual (cf. GOLDMAN, Alvin. Liaison: Philosophy meets the cognitive and social sciences. Cambridge: The MIT Press, 1991, pp. 155 ss.) 
clarividência; ou (c) tal pessoa tem boas razões para acreditar que tal poder não pode ser possuído (e.g., ele poderia requerer a transmissão de alguma influência a uma velocidade maior do que a da luz); ou (d) tal pessoa não possui evidências contra ou a favor da possibilidade geral do poder, assim como contra ou a favor da proposição em que ele crê como resultado de seu poder (aquela de que o Presidente está em Nova Iorque)." ${ }^{23}$

Neste caso temos um choque de intuições: a suposição externalista de que tal sujeito epistêmico possui conhecimento (já que o processo que produziu a crença é, efetivamente, confiável) parece ser incompatível com as evidências que, interna e conscientemente, ele possui contra o processo produtor da crença.

O problema da Meta-Incoerência, a nosso ver, mostra com perfeição o choque entre as intuições internalistas e externalistas. Consideramos, seguindo uma longa tradição, que o que pode nos interessar, em primeiro lugar, é a posse de crenças sobre a confiabilidade daquilo que justifica nossas crenças (ou seja, crenças de segunda ordem). Este parece ser o tipo de conhecimento que já foi denominado por Sosa como o conhecimento "humano" ${ }^{24}$ (e é sobre as crenças de segunda ordem que se instala, por exemplo, um dos ceticismos filosoficamente mais interessantes, o ceticismo de segunda ordem, o que ataca exatamente a nossa suposição de que certa forma de conexão entre crenças é adequada). Nós não queremos apenas saber; nós queremos ter o direito epistêmico de afirmar que sabemos.

\subsubsection{Respostas goldmanianas para o Novo Problema do Demônio Maligno}

Vejamos, agora, como Goldman se defenderá dos três ataques. Comecemos discutindo o Novo Problema do Demônio Maligno. Relembrando, ele nos apresenta um caso em que indivíduos possuem um equipamento de formação de crenças (métodos e processos) idêntico ao nosso mas vivem em um mundo alternativo, controlado por um demônio da família daquele que assombrava Descartes. Se nossos processos são (uma concessão para fins do exemplo) confiáveis, o que dizer dos processos que equipam nossos gêmeos? Afinal, os processos são idêntiCos aos nossos. Mas, por outro lado, diferentemente dos nossos, tais processos produzem mais crenças falsas do que verdadeiras.

Goldman se ocupa deste problema primeiramente em Epistemology and cognition. A esta altura, sua abordagem lidava com o problema apelando para a noção de mundo normais. A noção de "mundo normal", que Goldman admite vaga ("mas não inútil"), pode ser entendida como o conjunto de mundos "consistentes com

23 SOSA, 1991, p. 132. Este problema foi proposto originalmente por Laurence Bonjour em Externalist theories of empirical knowledge, em Midwest Studies in Philosophy, Vol. 5: Studies in Epistemology, ed. P. French et al. (Minneapolis: University of Minnesota Press, 1980).

24 Ou conhecimento reflexivo, que é possuído se "o julgamento ou a crença do indivíduo manifesta não apenas aquela resposta direta ao fato conhecido, mas também entendimento do seu lugar em um todo amplo que inclui sua crença ou conhecimento disso e de como isso se deu" (Knowledge in perspective, p. 240) 
nossas crenças gerais sobre o mundo real". ${ }^{25}$ Ele sustentará, daí, que o "nosso conceito de justificação é construído contra o pano fundo de tal conjunto de mundos normais", ${ }^{26}$ e que

de acordo com nossa concepção ordinária de justificação, um sistema é correto em qualquer mundo $\mathrm{W}$ apenas no caso de apresentar uma taxa de produção de verdades suficientemente alta nos mundos normais. A correção é enrijecida para todos os mundos; mas é enrijecida como uma função da confiabilidade em mundos normais, não [em função da] confiabilidade no mundo real. A correção de regras - e, daí, a justificação - revela um chauvinismo de mundos normais. ${ }^{27}$

Dado isto, os nossos gêmeos habitantes do mundo manipulado possuirão crenças justificadas se o mundo em que vivem fizer parte de um conjunto de mundos normais e se os processos de aquisição de crenças para eles disponíveis forem confiáveis na maior parte destes mundos. Como o mundo manipulado não é um mundo normal, os processos não devem ser considerados confiáveis e as crenças por eles produzidas não são justificadas.

Esta solução do problema falha, porém, pelas seguintes razões (além do seu claro caráter de consideração ad hoc): primeiramente, como o próprio Goldman já admitia em Epistemology and cognition, a noção de mundo normal é demasiadamente vaga. Ela não esclarece o que são crenças gerais sobre o mundo e não indica quais ou quantas crenças devem ser comuns para que um dado mundo faça parte de um conjunto de mundos normais. Em segundo lugar, considerando que num mesmo mundo (no nosso, ao menos) podemos encontrar indivíduos com crenças gerais muito distintas sobre o mundo, que crenças devemos considerar quando desejarmos comparar este mundo com um dado conjunto de mundos normais?

Por fim, a idéia de que o conjunto de regras de justificação correta em todos os mundos possíveis é determinado pela correção do conjunto de regras em um determinado conjunto de mundos normais é, como o próprio Goldman admite, chauvinista. Imagine que nosso mundo seja único no universo, num certo sentido, e que esta singularidade seja, para nós, algo que caracteriza nosso mundo, distinguindo-o significativamente dos demais. Há outros mundos que nós consideramos significativamente semelhantes entre si. O conjunto de mundos normais, neste caso, tem como membro apenas o nosso mundo. O conjunto que inclui os demais mundos tem numerosos membros. Neste caso, por que devemos pontificar sobre a confiabilidade de um processo na maioria dos mundos considerando apenas o nosso mundo?

25 Ibid. É importante perceber que o que é solicitado aqui não é similitude dos mundos, mas das crenças de seus indivíduos sobre os mundos. Considerando que aqueles indivíduos manipulados pelo demônio cartesiano desconhecem sua real situação, mas, apesar disso, possuem crenças sobre o mundo (mesmo que crenças falsas) semelhantes às crenças que nós temos sobre o mundo em que vivemos (concedendo que nós não vivemos em um ambiente manipulado), podemos aceitar que o mundo manipulado e o nosso mundo fazem parte de um mesmo conjunto de mundos normais

26 Epistemology and cognition, p. 107. Grifo nosso.

27 Ibid. 
A insuficiência da solução proposta em 86 será reconhecida pelo próprio Goldman, em seu ensaio de 1988, Strong and weak justification, ${ }^{28}$ que propõe que abandonemos a abordagem baseada nos mundos normais, substituindo-a por uma nova distinção: a distinção entre dois tipos de justificação, a forte e a fraca.

Quando uma crença está justificada de modo forte ela

(justificação forte): $S$ está justificado ao crer em $p$, de modo forte, se "é uma crença (grosso modo) bem formada, uma crença formada (ou sustentada) por métodos, procedimentos ou processos adequados, apropriados ou convenientes". ${ }^{29}$

Uma crença está, por sua vez, justificada de modo fraco se

(justificação fraca): $S$ está justificado ao crer em $p$, de modo fraco, se "(1) O método $M$ através do qual a crença é produzida é não-confiável (isto é, não suficientemente confiável), mas (2) $S$ não acredita que $M$ seja não-confiável, e (3) $S$ não possui e não está disponível para ele/ela um meio confiável para descobrir que $M$ não é confiável. (...) e (4) não há qualquer processo ou método que $S$ crê confiável, o qual, se utilizado, levaria $S$ a crer que $M$ não é confiável". ${ }^{30}$

A estratégia subjacente à definição é clara: premiar um eventual indivíduo que, apesar de se encontrar numa situação epistemicamente adversa, pode ser considerado como isento de culpa. Assim, apesar de ele possuir crença produzida por processo não-confiável, ele não é réu em qualquer acusação de desleixo intelectual: não há sequer um método que ele meramente considere confiável (mesmo que de fato não o seja) e que o levaria a descrer na confiabilidade dos processos produtores de crenças de primeira ordem.

Voltemos a visitar nossos pobres gêmeos, no mundo diabolicamente manipulado. Podemos sustentar que, dado o grau de manipulação a que eram submetidos, as condições (2), (3) e (4) previstas na definição de justificação fraca são cumpridas (supondo que o demônio manipulador não deixa rastros de sua existência e que, por outro lado, oferece a suas vítimas uma ilusão coerentemente organizada). Sendo assim, eles dispõem de justificação fraca para suas crenças (já que a condição (1) também é cumprida). Os processos que efetivamente produzem crenças (ao menos os processos independentes-de-crença) são, porém, processos nãoconfiáveis. Logo, os habitantes do mundo diabolicamente manipulado não possuem justificação forte para suas crenças.

A distinção entre justificação forte e fraca pode parecer, num primeiro momento, uma resposta adequada ao Novo Problema do Demônio Maligno. A distinção parece captar o curioso estado em que se encontram os habitantes do mundo

${ }^{28}$ GOLDMAN, Alvin. Strong and weak justification. In. TOMBERLIN, James (Ed.). Philosophical perspectives, 2, Epistemology, 1988. Atascadero: Ridgeview, 1988. Reimpresso em Liaisons - Philosophy meets the cognitive and social sciences. Cambridge: The MIT Press. As referências bibliográficas serão a esta reimpressão.

29 Strong and weak justification, p. 128

30 Strong and weak justification, pp. 131-2. Goldman aceita que este conjunto de condições é necessário, mas não garante sua suficiência. Além disso, cabe notar que estamos, aqui, no nível dos métodos. Uma apresentação da noção deve ser feita para o nível dos processos (e será similar a esta). 
demoníaco, o de condenação sem culpa: estão condenados à falsidade, mas não por erro seu. Dada a distinção entre justificação forte e fraca, eles passam a ser agraciados com justificação, o prêmio pela ausência de culpa, mas não recebem o prêmio completo, já que, a despeito de sua inocência, suas crenças são falsas e produzidas de modo inadequado.

Uma questão permanece, porém, em aberto: devemos avaliar se esta distinção não possui caráter ad hoc. A resposta, a nosso ver, será afirmativa, e mostraremos sua adhocidade com um teste simples: verificaremos se ela é útil quando tratamos de indivíduos em ambientes não-manipulados (um ambiente como, supostamente, o nosso).

A questão a ser posta é a seguinte: pode alguém, num ambiente nãomanipulado, possuir justificação fraca? A resposta é negativa: num ambiente nãomanipulado sempre podemos esperar que esteja disponível para o sujeito epistêmico um meio confiável para descobrir que os processos de formação de crença não são confiáveis. Afirmar o mesmo quando tratamos de métodos para a produção de crenças seria um pouco mais arriscado. Processos, porém, relembrando, são mecanismos psicologicamente mais básicos para a produção de crenças. Se o ambiente não é manipulado, podemos então esperar que os processos representem uma relação adequada do sujeito com o ambiente e que, por isso, sempre exista um modo de fazer com que a inadequação do processo, mais cedo ou mais tarde, se revele. De qualquer modo, o escopo da distinção justificação forte/fraca se restringe aos mundos manipulados. A única função da distinção é, então, a de oferecer uma resposta ao problema. Ela é, pois, ad hoc.

O acompanhamento da introdução da distinção justificação fraca/forte tem, para o escopo de nossa investigação, uma importante função exegética: a distinção, como já vimos, fornece uma resposta ao Novo Problema do Demônio Maligno que se distingue substancialmente daquela resposta sugerida em Epistemology and cognition. De modo especial, a distinção vem acompanhada da idéia de que não devemos tomar a confiabilidade de modo rígido (como pressuposto pela teoria dos mundos normais, esboçada por Goldman em 1986). Retornaremos a este ponto durante a discussão sobre o problema da generalidade.

\subsubsection{A resposta goldmaniana para o Problema da Generalidade}

O problema da generalidade, como já indicamos, foi reconhecido por Goldman já em What is justified belief? Uma resposta - mesmo que tímida - para o problema, porém, só foi apresentada em Epistemology and cognition. A resposta proposta se vale de dois pressupostos: o primeiro consiste na idéia de que a confiabilidade global pode ser mais bem compreendida como uma propensão, não como freqüência; a segunda idéia é a de que podemos determinar um modelo mínimo de processo, que é o "modelo [type] mais estreito que é causalmente operativo na produção de uma instância de crença em questão".

31 Epistemology and cognition, p. 50. 
Confiabilidade global é "confiabilidade para todos (ou muitos) usos do processo, não apenas o seu uso na formação da crença em questão. Confiabilidade local diz respeito apenas à confiabilidade do processo no contexto da crença sob avaliação". ${ }^{32}$ Confiabilidade global é determinada como uma "taxa entre instâncias, então, falando de modo estrito, ela está ligada apenas a um modelo [type] de processo". "Isso impede, segundo Goldman, que a variação Caso Único do Problema da Generalidade (aquela em que um processo é tão específico que produz, ao longo do período de funcionamento, apenas uma crença) se instale, já que isto pode ocorrer somente se "a confiabilidade global é determinada exclusivamente pelas freqüências reais", ${ }^{34}$ o que não é o caso, já que ela é, antes, uma propensão.

Há, obviamente, muita obscuridade aqui. Primeiramente, a idéia de propensão precisa ser esclarecida; é necessário, por exemplo, que seja explicada a relação entre a propensão para a verdade e a freqüência real da ocorrência de verdades. Se a propensão for determinada apenas a partir das freqüências reais, então o recurso a tal noção nada mais é do que um adiamento do enfrentamento com o problema, não uma solução; se a propensão é determinada de alguma outra maneira (por exemplo, se a propensão é determinada também levando em conta a expectativa de como funcionaria o processo em situações hipotéticas), então Goldman fica a nos dever uma explicação.

No outro extremo, temos o Problema da Não-Discriminação. O tratamento deste aspecto do problema é mais promissor: ele apela para a idéia do estabelecimento de um critério para a seleção do modo de descrição dos processos de produção de crenças. O critério é simples: o processo deve ser sempre descrito usando o modelo crítico [critical type], que consiste no "modelo mais estreito que é causalmente operativo na produção do exemplar de crença em questão". " O próprio Goldman nos esclarecerá:

Para ilustrar esta idéia, suponha (para fins meramente ilustrativos) que existe um modelo de mecanismo para a formação de crenças pela percepção. O mecanismo recebe dados de entrada dos sistemas sensórios e tenta os encaixar entre vários padrões, cada padrão representando uma categoria C, por exemplo, a categoria dos cães, a categoria dos carros ou a categoria das cadeiras. Suponha que o mecanismo funciona de tal maneira que existe um valor $\mathrm{T}$ tal que se os dados de entrada se encaixam na categoria C para o grau T ou maior, então o mecanismo gera uma crença de que o objeto gerador do estímulo pertence à categoria $\mathrm{C}$. Porém, se o valor de $\mathrm{T}$ é muito baixo, então quando o estímulo está altamente degradado - parcialmente obscurecido, ou visto sob condições adversas de iluminação - dados de entrada resultantes do estímulo podem levar a uma crença de que o estímulo pertence a C. Suponha que tal crença, em uma dada ocasião, é verdadeira. Devemos chamá-la de conhecimento? Certamente deveríamos desconfiar desta intenção. A nossa relutância pode ser explicada ao se apontar para a não-confiabilidade do mecanismo. Um mecanismo do tipo postulado, com um limiar baixo de enquadramento, tenderá a ser bastante não-confiável. Na me-

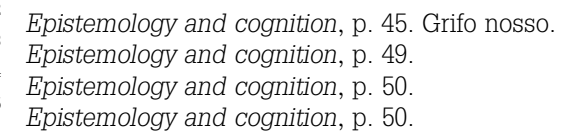


dida em que o valor do limiar de enquadramento é incluído no modelo de processo escolhido, nós atingiremos a resposta correta neste caso de atribuição de conhecimento.

Mas perceba que o mecanismo tem muitas propriedades de enquadramento diferentes. Ele tem a propriedade de produzir uma crença quando o grau de enquadramento é $\mathrm{T}+.1$; tem a propriedade de produzir uma crença quando o grau de enquadramento é $\mathrm{T}+$.2; e assim por diante. É o modelo apropriado de processo sempre um que inclui a primeira destas propriedades, nomeadamente, o grau mínimo de enquadramento suficiente para a crença? Presumivelmente não. Considere um caso no qual a entrada não está degradada, e o grau efetivo de enquadramento no padrão é de, digamos, .99 (numa escala de 0 a 1). Então, presumivelmente, nós desejaremos dizer que isto é adequado para o conhecimento (se tudo o mais ocorre adequadamente). Mas, se o modelo de processo selecionado ainda incluir o valor mínimo T, o modelo, como um todo, pode não possuir confiabilidade suficiente. ${ }^{36}$

A idéia de modelo crítico tem seu apelo; ela utiliza exatamente as novas ferramentas que o confiabilismo pretende trazer para o cenário epistemológico, aquelas procedentes das ciências cognitivas. Trata-se de uma boa aposta: se os cientistas forem capazes de, de alguma maneira, estabelecer limites para o funcionamento de um dado elemento do nosso equipamento cognitivo, este elemento ficaria imune ao problema da generalidade. Imagine, por analogia, um circuito eletrônico; ele funciona apenas quando estimulado por uma certa faixa de entrada. Acima ou abaixo dos valores de corte, o circuito simplesmente não é ativado. Se nosso aparelho cognitivo funciona, de alguma maneira, de modo semelhante, o problema da generalidade se dissolve. É claro, porém, que isto permanece como um condicional.

\subsubsection{Uma resposta para o Problema da Meta-Incoerência}

Relembrando, no problema da Meta-Incoerência temos casos em que, de modo geral, chocam-se as evidências do sujeito $\mathrm{S}$ contra o processo causador de uma proposição $\mathrm{p}$ e o fato de $\mathrm{p}$ ter sido produzida por um processo efetivamente confiável. A resposta Goldmaniana padrão ao problema é previsível: vimos, na definição (P3), uma cláusula perfeitamente adequada para o tratamento do problema. Como vimos, (P3) previa que um sujeito epistêmico está justificado em crer em um uma proposição se e somente se (a) a crença de $\mathrm{S}$ em p em t é permitida por um sistema correto de Regras-J, e (b) esta permissão não é desqualificada pelo estado cognitivo de S, em t. E, como podemos facilmente perceber, nos casos do problema da Meta-Incoerência a condição (b) não é satisfeita.

É hora, pois, de atentarmos para (b). O "estado cognitivo" do sujeito, capaz de desqualificar uma crença, parece incluir (Goldman não é preciso neste ponto) a possibilidade da existência de crenças de ordem superior sobre a crença em questão ou sobre o processo causador da crença. Goldman reconhece que em Epistemology and cognition ele "não tenta oferecer uma teoria completa da desqualificação" ${ }^{37}$ mas adianta alguns modos pelos quais a desqualificação pode ocorrer:

Epistemology and cognition, p. 50-1

Epistemology and cognition, p. 62. 
primeiro, a crença pode ser desqualificada quando o conhecedor crê com permissão [de um conjunto de Regras-J] que a crença não é permitida. Segundo, a crença pode ser desqualificada pela crença do conhecedor de que ela não é permitida mesmo quando a crença de ordem superior não é, ela mesma, permitida. Mas possibilidades adicionais devem ser consideradas. O sujeito conhecedor poderia não possuir o conceito de permissão para uma crença, ou ainda de regras corretas. Mas suponha que o conhecedor acredita que certas condições não são satisfeitas, quando tais condições são de fato necessárias para que a crença seja permitida. Este é um terceiro modo, eu penso, pelo qual a permissão para crer pode ser abalada. ${ }^{38}$

Uma questão aqui nos parece crucial: porque devemos aceitar que uma crença de ordem superior possa, em qualquer caso, desqualificar a permissão para uma dada crença? Isto é claramente aceitável nos casos em que a confiabilidade do processo que gera a crença de ordem superior é, ela mesma, de grau mais elevado. Um processo mais confiável certamente deve ser capaz de cancelar a justificação disponível para uma crença obtida através de um processo menos confiável. Mas não há, a nosso ver, nada no projeto confiabilista que justifique a opção por uma gama mais ampla de casos de cancelamento da justificação. O "estado cognitivo" de um sujeito - e Goldman não esclarece o significado desta expressão - pode consistir em um conjunto de crenças com péssimo histórico de formação. Considerando-se apenas os postulados assumidos por Goldman, por que devemos aceitar que uma crença formada por má indução, por exemplo, possa cancelar a justificação de uma crença produzida, por exemplo, pela visão em condições favoráveis? Apenas o fato de esta crença ser, em relação à outra, de grau superior? Não nos parece que Goldman possa aceitar isto sem trincar os pressupostos mais básicos de seu projeto, sem agredir violentamente os pressupostos meta-epistemológicos que assumiu.

A questão se revela ainda mais dramática quando notamos que qualquer crença autocondenatória sobre o estado cognitivo de um sujeito pode anular a justificação que, em $t, S$ tem para $p$, como mostrou Cláudio de Almeida. Ele nota que

será, certamente, óbvio que qualquer epistemologia defensável deve abrigar a possibilidade do meta-conhecimento - i. e., deve abrigar a possibilidade de que uma pessoa saiba que sabe que p quando ela sabe que p. No entanto, nenhuma epistemologia para a qual a justificação epistêmica seja condição necessária para o conhecimento poderá acomodar essa possibilidade, a menos que incorpore o seguinte princípio: S está justificado ao crer que p em t somente se não é o caso de que, em t, S crê que não está justificado ao crer que p em t. Se S crê, falsamente, que não está justificado ao crer que $p$, então, enquanto mantém essa crença falsa, $S$ não pode saber que sabe que $p$ mesmo que ele, de fato, saiba que p; pois, para saber que ele (presentemente) sabe que p, ele teria de ter uma crença que implica que ele (presentemente) está justificado ao crer que p - a saber: 'Eu (presentemente) sei que p ${ }^{39}$

38 Epistemology and cognition, p. 62.

ALMEIDA, Cláudio de Uma versão do deontologismo epistêmico. In SOUZA, Draiton G. (Org.). Amor scientiae: festschrift em homenagem a Reinholdo Aloysio Ullmann (Porto Alegre: EDIPUCRS, 2002, pp121-35). Confira também de ALMEIDA, What Moore's paradox is about. Philosophy and phenomenological research, 2001, vol. 62, no. 1, pp. 1-26. Com este argumento, ele pretende vindicar observações de Ernest Sosa, Richard Foley e Keith Lehrer contra a meta-incoerência (a purgação de elementos da vida mental do agente que sirvam de base à autocondenação) que não lhe parecem bem-defendidas em suas obras. 
A noção de confiabilidade parece ser insuficiente para satisfazer as exigências para o metaconhecimento, e isto é revelado pelo problema da Meta-Incoerência. Goldman reconhece o impacto do problema, mas incorpora as armas para enfrentá-lo de um modo que nos parece ser ad hoc.

\subsection{Do confiabilismo para uma teoria das virtudes intelectuais}

As respostas de Epistemology and cognition para os três problemas apresentados, como acabamos de ver, não são, em geral, satisfatórias. Como já indicamos anteriormente, porém, Goldman incorporará ao confiabilismo um novo conceito - o conceito de virtude intelectual. O leitor poderá acompanhar, agora, a reconstrução de tal conceito (conforme a proposta de Emest Sosa), o modo como, segundo Sosa, sua teoria responderá aos três problemas e, por fim, o modo como o próprio Goldman incorporará a noção de virtude ao confiabilismo.

\subsubsection{Sosa: as virtudes intelectuais e os problemas do confiabilismo}

A noção de virtude intelectual debuta no cenário da discussão epistemológica contemporânea em The raft and The pyramid: coherence versus foundations in the theory of knowledge. ${ }^{40}$ Neste ensaio, Ernest Sosa sugere uma solução para um impasse no debate fundacionismo/coerentismo. O impasse pode ser resumido nestes termos: o coerentismo - representado metaforicamente pela balsa, flutuando livre de amarras - é incapaz de acomodar adequadamente as crenças perceptuais. Isto se dá porque o coerentismo toma - na visão de Sosa - a justificação como resultante das relações lógicas entre as crenças do sistema de crenças; mas as crenças perceptuais nem sempre mantêm relações com o restante do sistema de crenças. ${ }^{41} \mathrm{O}$ fundacionismo - a pirâmide - é capaz de acomodar adequadamente as crenças perceptuais, mas é vítima de um dilema: se pensamos sobre o "princípio epistêmico que fornece a justificação para crermos que algo é vermelho, baseados na nossa experiência visual de algo vermelho, ele é pensado como um princípio fundamental ou como uma generalização derivada?". ${ }^{42}$ Se a primeira opção é correta, então teremos uma multiplicidade de "princípios fundamentais", já que poderemos ter princípios diferentes para experiências visuais, auditivas, táteis, etc. Para a segunda opção temos outro problema: se o fundacionista sustenta que se trata de uma generalização derivada, então ele fica a nos dever uma apresentação deste princípio unificador mais profundo. ${ }^{43}$

40 In. FRENCH, UEHLING \& WETTSTEIN (Eds.), Midwest studies in Philosophy - Volume V - Studies in epistemology. Minneapolis: University of Minnesota Press, 1980, pp. 3-25.

41 Uma exposição crítica de uma das principais teorias coerentistas da justificação - proposta por Keith Lehrer, pode ser encontrada em LUZ, Alexandre M. O que significa 'conhecer'? O problema de Gettier e três tentativas internalistas de Solução. Porto Alegre: Dissertação: PUCRS, 1997.

42 The raft and the pyramid, p. 21.

43 A reconstrução de uma teoria fundacionista (a teoria fundacionista de Paul Moser) pode ser encontrada em LUZ, Alexandre M. O que significa 'conhecer'? O problema de Gettier e três tentativas internalistas de solução. Porto Alegre: Dissertação: PUCRS, 1997. 
O dilema não é efetivamente superado em The raft and the pyramid. Àquela altura, Sosa apenas sugere que a justificação seja estratificada em justificação primária e justificação secundária e que a justificação primária "poderia recorrer às virtudes intelectuais, a disposições estáveis para aquisição de crenças, devido à sua grande contribuição em favor de nossa condução até a verdade". ${ }^{44}$

A efetiva introdução, por Sosa, de uma noção substancialmente desenvolvida de virtude intelectual se dará em 1985, com Knowledge and intellectual virtue $;^{45} \mathrm{O}$ tratamento completo da noção, porém, só é apresentado em 1991, em Reliabilism and intellectual virtue e em Intellectual virtue in perspective. ${ }^{46}$ Nesses ensaios, Sosa mostra que o confiabilismo não é capaz, com as ferramentas disponíveis até então, de responder aos problemas da generalidade, da Meta-Incoerência e ao Novo Problema do Demônio Maligno, e propõe, alternativamente, um tratamento baseado na noção de virtude intelectual. Acompanharemos, primeiramente, as críticas de Sosa às respostas goldmanianas para os problemas; depois, o modo como elas permitirão que nos aproximemos da noção de virtude (e, daí, da teoria sosiana do perspectivismo das virtudes); por fim, as respostas sosianas para os três problemas.

Comecemos com o Novo Problema do Demônio Maligno. Como vimos, a última resposta goldmaniana para o problema se utiliza das noções de justificação forte e de justificação fraca. A crítica de Sosa será dirigida a esta última noção. Como mostramos, em Strong and weak justification, Goldman sustenta que uma crença está fracamente justificada se e somente se

[a crença] é bem formada, no sentido de ter sido formada por meio de um processo que é conducente à verdade no mundo possível em que ela é produzida. ${ }^{47}$

Sosa observa que é

[...] no máximo num sentido muito fraco que o sujeito que possui uma crença "fracamente justificada" é, por isso, "isento de culpa". Isto porque não é vetado que o sujeito tome a crença como sendo muito mal-formada, enquanto se encontra em erro sobre o processo cognitivo que a produz. Isto significa dizer que $\mathrm{S}$ poderia aceitar $\mathrm{B}$, e crer que $\mathrm{B}$ é o resultado de $\mathrm{P}$, e crer que $\mathrm{P}$ é um processo epistemicamente não-confiável, enquanto, de fato, não é $\mathrm{P}$ que produz $\mathrm{B}$, mas sim o processo P', igualmente nãoconfiável. Neste caso a crença B de S poderia estar fracamente justificada, enquanto S não crê que P' é não-confiável, e enquanto S não possuía meios disponíveis para determinar sua não-confiabilidade. Parece, porém, no mínimo forçado tomar S como epistemicamente "sem culpa" com respeito à aceitação de B em tais circunstâncias, quando S toma B como derivando de um processo P não confiável a ponto de ser epistemicamente vicioso. ${ }^{48}$

Id., p. 23

45 Publicado inicialmente em The Monist, 68, 1985, pp.224-45 e reimpresso como o capítulo 13 de Knowledge in perspective.

${ }^{46}$ Que vêm a ser o oitavo e o décimo sexto capítulos de Knowledge in Perspective.

47 Strong and weak justification, p. 56.

48 Knowledge in perspective, p. 133-4. Note que aqui Sosa realiza um movimento interessante: a despeito da existência de crenças de segunda ordem - crenças sobre o processo formador da crença em questão, é a efetiva confiabilidade do processo que funciona, em última análise, como avaliador da condição epistêmica do sujeito. As crenças de segunda ordem são consideradas inadequa- 
No caso do Problema da Meta-Incoerência, segundo Sosa, o sujeito epistêmico é culpável por outra razão: ele não dispõe de uma perspectiva adequada em relação à crença em questão (a crença resultante do processo confiável de clarividência) e, por isso, a descarta, quando deveria aceitá-la (já que o processo que a produz é confiável). Ele não está, então, justificado em descartar a crença.

O problema com a abordagem goldmaniana, segundo Sosa, é sua incapacidade de oferecer um tratamento adequado da justificação subjetiva. Poderemos realizar tal tarefa, ele sustenta, através da incorporação da noção de virtude intelectual. No Problema da Meta-Incoerência e no Novo Problema do Demônio Maligno o ponto parece ser a inexistência de uma conexão adequada com o ambiente (no caso da Meta-Incoerência, antes, um problema de informação inadequada sobre a conexão do indivíduo com o ambiente). Mas, Sosa observa, "se a causa do erro está no ambiente, ela poderia impedir o sujeito de saber aquilo em que ele crê, mesmo se sua crença fosse verdadeira, mas há um sentido no qual o sujeito permaneceria subjetivamente justificado ou seria, de algum modo, virtuoso em tal crença. É este sentido de virtude interna que parece mais significativo para que lidemos com o Novo Problema do Demônio Maligno e com a objeção da MetaIncoerência". ${ }^{49}$

Em primeiro lugar, pois, o conceito de virtude intelectual deve incorporar a relação desejada entre certas faculdades internas estáveis (uma virtude, obviamente, é uma faculdade interna do sujeito) e o ambiente. Mas que faculdades internas? Sosa é amplamente permissivo: podemos considerar uma virtude qualquer evento interno (dadas outras condições, obviamente), desde os processos psicologicamente mais básicos até os mais complexos. ${ }^{50}$

Temos o suficiente para a apresentação de uma definição preliminar: "Vamos definir uma virtude ou faculdade intelectual como uma competência em virtude da qual alguém pode, na maioria dos casos, obter a verdade e evitar o erro em um certo campo de proposições F, quando sob certas condições C". ${ }^{11}$ Esta definição preliminar já traz novidades em relação ao confiabilismo: as idéias de campo de proposições e a idéia de um conjunto de condições no qual a competência é, efetivamente, produtora-de-verdades. Mas estas novas noções merecem, por sua vez, esclarecimento. Um tratamento mais completo é oferecido por Sosa. De alguém pode ser dito possuir uma virtude intelectual se:

Devido a certa natureza interna (I) [inner nature] possuída pelo sujeito $\mathrm{S}$, que está situado em um certo ambiente (E), S estaria, provavelmente, correto no que concerne a qualquer proposição X do campo F, em relação a qual S está nas condições C. S pode-

\footnotetext{
das porque não indicaram a não-confiabilidade do processo. Este movimento, a nosso ver, deixa Sosa mais próximo do confiabilismo original do que o próprio Goldman (dadas, por exemplo, as suas considerações sobre crenças de segunda ordem, que acompanhamos anteriormente).

49 Knowledge in perspective, p. 140.

Também o confiabilismo goldmaniano utiliza-se da idéia de uma base de processos fundamentais (que "podem ser largamente inatos", segundo Sosa) sustentando processos derivados através do exercício dos fundamentais.

51 Knowledge in perspective, p. 138.
} 
ria ser um humano; I poderia envolver a posse de bons olhos e de um bom sistema nervoso, incluindo um cérebro em bom estado; E poderia incluir a superfície do globo terrestre, com suas propriedades relevantes, dentro dos parâmetros de variação experimentados pelos seres humanos através dos séculos, ou pelo sujeito $S$, durante sua vida ou durante um período determinado dela; F poderia ser um campo de proposições especificando as cores ou formato de um objeto diante de S, dentro de um certo nível de determinação e complexidade (digamos, verdicidade e quadradicidade, mas não verde-amarelicidade ou quiliagonicidade); e C poderiam ser as condições de S ver tal objeto sob boa luz, ao alcance da mão e sem nenhuma obstrução. ${ }^{52}$

A estratégia que guia a formulação da noção de virtude intelectual (na obra de Sosa) está já suficientemente clara: enquanto o confiabilismo trabalhava, em última análise, com o par 'processo produtor de crença-confiabilidade', a noção de virtude intelectual se vale de um quadro mais amplo, que inclui confiabilidade, ${ }^{53}$ process ${ }^{54}$ e contexto. ${ }^{55}$

O tratamento da noção de virtude intelectual é, pois, novo e bastante distinto daquele oferecido pela tradição aristotélica. ${ }^{56}$ Uma virtude intelectual, para Sosa, não é, ela mesma, uma disposição estável, num sentido absoluto. A disposição estável é, antes, aquilo que ele denomina base da virtude, ou seja, a natureza interna I. Uma virtude intelectual é estável apenas num sentido relativo, relativo ao ambiente E. Se, na terminologia sosiana, denominamos alguém de "virtuoso", devemos considerar que estamos apenas dizendo que esse sujeito, grosso modo, tende a estar certo em relação a uma proposição num dado ambiente. E nada podemos inferir sobre sua virtuosidade em relação a outros ambientes. Aquela disposição interna que serviu adequadamente de base para uma virtude relativa a E pode não servir adequadamente como base para uma virtude relativa a um ambiente semelhante E'. Por fim, podemos também aceitar que uma mesma virtude possua diferentes bases, para diferentes indivíduos. Podemos imaginar, apenas para fins de exemplo, que dois indivíduos utilizem diferentes mecanismos cerebrais para realizar as mesmas operações matemáticas, com igual grau de sucesso. Os dois indivíduos são, a despeito das suas diferenças cognitivas, virtuosos.

52 Knowledge in perspective, p. 139.

53 Sosa não utiliza a noção goldmaniana de "confiabilidade"; um requisito análogo, porém, fica mantido: nas condições adequadas, o sujeito virtuoso tem mais chances de estar correto em relação à proposição em questão.

54 Sosa também não utiliza o termo "processo". Ele é substituído pelo conceito mais amplo de "natureza interna".

55 O que chamamos aqui de "contexto" (o termo é nosso) é representado pelo trio "ambiente", "condições" e "campo de proposições".

56 Sosa admite uma "concepção estreitamente aristotélica de virtude, de acordo com a qual uma virtude é uma disposição para fazer escolhas deliberadas apropriadas". Mas considera também a existência de "um sentido amplo de "virtude", também grego, no qual qualquer coisa com uma função - natural ou artificial - possui virtudes. O olho tem, no fim das contas, suas virtudes, assim como uma faca" (Knowledge in perspective, p. 271). De fato, ao fim do primeiro livro da República, o diálogo entre Sócrates e Trasímaco revela a suposição platônica; Sócrates pergunta - e Trasímaco aquiesce - "se cada coisa desempenha bem a sua função por virtude e mal pelo vício contrário" (PLATÃO, A República. São Paulo: Nova Cultural, 1997, p. 39). É neste sentido que Sosa utiliza o conceito. 


\subsubsection{Virtudes intelectuais: resposta aos problemas do confiabilismo}

Vamos agora acompanhar as respostas da teoria sosiana das virtudes intelectuais para os três problemas discutidos. Começaremos com o par Novo Problema do Demônio Maligno - Problema da Meta-Incoerência.

Como vimos, a dificuldade do Novo Problema do Demônio Maligno consiste em conceder aos nossos gêmeos manipulados o devido mérito (afinal, suas crenças são adequadas, dadas as informações que recebem - e que, eles não o sabem, são distorcidas pelo demônio) e, simultaneamente, a eles não conceder méritos indevidos (já que, claramente, sua condição é lastimável).

Os habitantes do mundo manipulado são semelhantes a nós em um aspecto significativo: sua natureza interna é idêntica à nossa. Como foi visto, porém, um sujeito é virtuoso quando possui uma excelência em um dado ambiente. Daí, podemos considerar que os habitantes do mundo manipulado não são virtuosos em relação ao mundo manipulado, mas são virtuosos - assim como nós - em relação ao nosso mundo. Isto é o suficiente para superar o impasse em que aqui caia o confiabilista: aquele que consistia em caracterizar a situação de confiabilidade ou inconfiabilidade dos processos de aquisição de crenças dos habitantes do mundo manipulado. ${ }^{57}$

Isso é, porém, uma explicação insuficiente da condição cognitiva dos habitantes do mundo manipulado. Eles - assim como nós - podem possuir um sistema de crenças coerente, a despeito das falsidades que compõem esse sistema. Isto é, sem dúvida, algo digno de mérito. A noção sosiana de virtude, porém, é incapaz de oferecer um tratamento adequado para esta espécie de mérito. A estratégia sosiana para a superação desta limitação consiste na divisão de trabalho: a utilização de dois conceitos distintos - "justificação" e "aptidão" - assim definidos:

A "justificação" de uma crença B requer que B tenha uma base em suas relações de inferência ou coerência com outras crenças na mente do crente - como na "justificação" de uma crença derivada de princípios profundos e, por isso, "justificada", ou a "justificação" de uma crença adotada através do reconhecimento de sua adequação aos princípios do sujeito, incluindo princípios como os sobre que crenças são permissíveis nas circunstâncias percebidas pelo sujeito. ${ }^{58}$

A "aptidão" de uma crença B relativa a um ambiente E requer que B derive do que, relativamente a E, é uma virtude intelectual, i. e., um modo de chegar à crença que produza uma preponderância apropriada da verdade sobre o erro (no campo de proposições em questão, no tipo de contexto definido por C). ${ }^{59}$

57 Relembrando, parecia ser inadequado considerar os processos de aquisição de crença dos habitantes do mundo manipulado como não-confiáveis, já que os mesmos processos eram considerados confiáveis no nosso mundo.

58 A definição de justificação proposta por Sosa, assim como as definições internalistas em geral, é vítima do assim-chamado "problema do isolamento". O problema se instala por conta da possibilidade de um sujeito possuir um conjunto de crenças justificadas mas falsas (como é o caso dos habitantes do mundo manipulado do Novo Problema do Demônio Maligno).

59 Knowledge in perspective, p. 289. Confira também os capítulos 1 e 14. Uma distinção semelhante será estabelecida por Sosa no que diz respeito ao conhecimento. Trata-se da distinção entre conhecimento animal e conhecimento reflexivo. Um sujeito "possui conhecimento animal sobre o seu ambiente, seu passado sua própria experiência se seus julgamentos e crenças sobre eles são res- 
Devemos notar que a noção de justificação, definida do modo acima, é aplicável ao habitante do mundo manipulado. Considerando que a ele é vedada consciência da sua lamentável situação, podemos aceitar que as crenças induzidas parecem, para ele, adequadas às informações disponíveis. Ele recebe informações dos sentidos, que julga confiáveis. Estas informações (é bem possível) não contradizem as crenças que ele dispõe sobre o mundo, sobre os seus processos de aquisição de crenças, etc. Um indivíduo zeloso pode possuir um sistema de crenças coerente, mesmo sob as garras do demônio manipulador, como já vimos. Neste caso, sob este aspecto, sua situação é louvável. Ele está, diria Sosa, justificado.

No Problema da Meta-Incoerência a situação do sujeito epistêmico é, como vimos, oposta a dos habitantes do mundo manipulado. Lá ele possui uma perspectiva epistemicamente inadequada de sua situação, da virtuosidade de seus mecanismos de aquisição de crenças. Para explicar sua situação, o binômio aptidão/justificação será novamente suficiente: as crenças provenientes do processo de clarividência são efetivamente resultados de uma virtude intelectual e, por isso, são aptas. Porém, como o sujeito tem crença incompatível com a existência de tal virtude, as crenças dela proveniente não estão justificadas.

A resposta sosiana para o Problema da Generalidade é, por sua vez, distinta das respostas aos problemas anteriores em um aspecto significativo: trata-se, antes, de uma tentativa de dissolução do problema. Sosa lembra que nosso interesse pela justificação deriva da sua tendência para

indicar um estado do sujeito que é importante e do interesse da sua comunidade, um estado de grande interesse e importância para uma espécie social que compartilha informações. Que estado? Presumivelmente, o estado de ser uma fonte fidedigna sobre um certo campo, em uma certa circunstância. Para que tal justificação seja alcançável e útil posteriormente, porém, o tipo de campo F e o tipo de circunstância C precisam ser projetáveis, e precisam ter alguma mínima possibilidade objetiva ao longo da vida dos membros normais da comunidade epistêmica. ${ }^{60}$

Deste desideratum podemos facilmente derivar duas condições a serem cumpridas no momento da delimitação de um campo de proposições F e de um conjunto C de circunstâncias:

(i) $\quad \mathrm{F}$ e $\mathrm{C}$ devem ser generalizados de modo útil por nós do mesmo modo que pela comunidade epistêmica de S (assumindo que ele é um de nós - e, se não o for, atribuições de conhecimento deverão poder ser indexadas ou relativizadas a tais comunidades);

(ii) $\mathrm{F}$ e $\mathrm{C}$ devem ser generalizados de modo útil pelo próprio sujeito quando ele, com o próprio esforço, sobe do conhecimento animal para o conhecimento reflexivo. ${ }^{61}$

postas diretas a seu impacto - e. g., através da percepção ou memória - com pouco ou nenhum benefício da reflexão ou do entendimento"; ele "possui conhecimento reflexivo se o seu julgamento ou crença manifesta não apenas tal resposta direta ao fato conhecido, mas também compreensão do seu lugar num todo mais amplo que inclui a crença e o conhecimento disso e como eles se dão". (Knowledge in perspective - cap. 13: Knowledge and intellectual virtue, p. 240). O conhecimento reflexivo, pois, satisfaz o requisito de acessibilidade dos internalistas.

Knowledge in perspective - cap. 16: Intellectual virtue in perspective, p. 282.

61 Id., p. 284. 
Este ato de generalização é considerado por Sosa como, ele mesmo, uma virtude, mais especificamente, uma virtude sobre virtudes. Tomando o segundo requisito, por exemplo, esta virtude de segunda ordem é adequada quando identifica o campo em que uma faculdade de primeira ordem - a visão, por exemplo - é efetivamente virtuosa.

A dissolução do problema é, pois, realizada - mas apenas no escopo da teoria sosiana: sob determinado aspecto, podemos ser virtuosos na primeira ordem (e por isto, aptos no que diz respeito a este aspecto), mas, se não somos virtuosos na segunda ordem (ou seja, se não determinamos de modo adequado o campo e as condições nos quais a faculdade de primeira ordem é, efetivamente, uma virtude), não satisfazemos aquele requisito de posse de uma perspectiva epistêmica adequada que é necessário para a justificação.

Em que consiste, porém, de modo mais preciso, tal "perspectiva adequada"? Esta é uma questão central, pois toca, por exemplo, em um dos pontos que demarcam os territórios do externalista e do internalista, a saber, o requisito de acessibilidade àquilo que justifica a crença. Se a "perspectiva epistemicamente adequada" for tomada como significando crença do sujeito epistêmico na origem virtuosa de uma crença-objeto em questão, então Sosa se compromete com o internalismo, de um modo inadmissível para Goldman (que, como vimos, dispensou o requisito de acessibilidade). Se a perspectiva adequada significa alguma outra coisa, então devemos requerer, obviamente, maiores esclarecimentos.

Pois bem, o próprio Sosa é deveras obscuro em relação a este ponto. Enquanto é tratado pela comunidade dos epistemólogos como um externalista, muitas vezes parece escrever como um internalista. Em um recente ensaio (Reflective knowledge in the best circles, ${ }^{62}$ de 1997), por exemplo, dissertando sobre a coerência requerida de alguém que se encontra em uma perspectiva adequada em relação às suas crenças, Sosa sustenta que

Esta concepção ampla da coerência da mente de uma pessoa envolve não apenas as relações lógicas, probabilísticas e explanatórias entre as crenças de primeira ordem da pessoa, mas também coerência entre tais crenças e as experiências sensoriais e de outras espécies que a pessoa realiza, e também coerência compreensiva entre experiências de primeira ordem, crenças e outros estados mentais, de um lado e crenças sobre estados de primeira ordem, do outro. ${ }^{63}$

A seção final do excerto soará tipicamente internalista, se imaginarmos que estas crenças de segunda ordem são formadas de modo tal que incluam acesso às crenças de primeira ordem, através da introspecção. O requisito por "crenças sobre estados de primeira ordem" revelaria, neste caso, compromisso com a tese de acessibilidade. E, já que virtudes são qualidades internas do sujeito, a teoria sosiana satisfaria os requisitos para uma classificação entre os internalistas.

62 In. The Journal of Philosophy, XCIV, n. 8, 1997. Reimpresso em STEUP, Matthias. Knowledge, truth and duty - Essays on epistemic justification, responsibility, and virtue. Oxford: Oxford UP, 2001, pp.187-202. (as páginas das referências a este ensaio dizem respeito a esta reimpressão)

Reflective knowledge in the best circles, p. 195. 
Que tipo de internalista, se este é o caso? Como vimos no excerto, aquela espécie de "coerência ampla" exigida para a perspectiva epistemicamente adequada inclui crenças advindas da percepção. Isso evita, segundo Sosa, que sua teoria seja vítima do Problema do Isolamento, que vitima teorias coerentistas que exigem, por exemplo, apenas que as crenças de um sistema estejam logicamente relacionadas entre si (o problema do isolamento mostra que um conjunto com crenças falsas pode ser coerente). O conhecimento reflexivo "requer coerência ampla, incluindo a habilidade da pessoa em colocar seu conhecimento de primeira ordem [suas crenças aptas] em perspectiva epistêmica". ${ }^{64}$ O conhecimento animal, porém, não exige qualquer tipo de coerência, como vimos anteriormente. Para o conhecimento animal é preciso apenas que a crença proceda de uma virtude (e sua teoria do conhecimento animal não é, pois, internalista). Sosa é, neste caso, um tipo incomum de coerentista: para o conhecimento reflexivo, sua teoria exige coerência, mas uma coerência de tipo ímpar, que inclui necessariamente crenças sobre a aptidão das crenças que compõem o conjunto de crenças do sujeito. ${ }^{65}$

O próprio Sosa, porém, não parece confortável em vestes internalistas. Em réplica a Richard Fumerton (veja a nota do final do final do parágrafo anterior), Sosa sustentará que aquele tipo de coerência exigida para que o sujeito epistêmico esteja numa perspectiva adequada em relação a uma crença não implica a existência de crenças de segunda ordem. Para tal,

[n]ós precisamos distinguir, primeiramente, entre crenças completamente conscientes e subconscientes; também, em segundo lugar, entre o que é e o que não é passível de verbalização ou simbolização pelo crente, talvez pelo menos em notação musical; e, finalmente, também entre crença que se manifesta através de atos de aceitação episódica de uma proposição de algum modo presente à mente de alguém, mesmo que não simbolicamente presente, e crença que é manifesta apenas de outros modos. Uma crença de que $2+2=4$ pode permanecer subconscientemente, mesmo quando alguém está adormecido e inconsciente; em segundo lugar, alguém pode acreditar que uma pessoa tem dada aparência ou que sua voz soa de tal modo, ou alguém pode saber que, em certa situação, para evitar desastres de bicicleta ele deve deslocar seu peso de uma dada maneira, ou deve virar o guidão de uma certa maneira, mesmo quando ele não consegue fazer isso, naquela situação. O conhecimento completo de como dirigir bicicletas pode ser algo que uma pessoa pode não expressar simbolicamente, mas a pessoa pode ainda manifestar tal conhecimento dirigindo efetivamente uma bicicleta e enfrentando de modo bemsucedido as situações que põem seu conhecimento à prova.

${ }^{64}$ Id., p. 196

Esta é, por exemplo, a posição de Richard Fumerton, que em nota do seu Sosa's epistemology defende que está "inclinado a pensar que devemos tomar a coerência como o requisito central para o conhecimento reflexivo. Conhecimento reflexivo é apenas crença verdadeira justificada na qual a justificação não contém qualquer falsidade essencial para a justificação. Justificação requer não apenas coerência, mas coerência de um tipo especial, coerência que inclui metacrenças sobre a origem da justificação. Estas metacrenças envolverão inevitavelmente crenças sobre a confiabilidade das fontes da crença e a "cláusula da ausência de falsidades essenciais" trará a confiabilidade para a teoria pela porta dos fundos, falando metaforicamente. Mas o tratamento da justificação relevante para o conhecimento reflexivo permanecerá essencialmente coerentista em estrutura". Esta é a nota 3 de FUMERTON, Richard. Sosa's epistemology. In. VILLANUEVA, Enrique (Ed.). Philosophical issues, 5 - Truth and rationality. Atascadero: Ridgeview, 1994. 
Algo similar pode ser dito dos procedimentos intelectuais. Alguém pode adquirir e sustentar crenças manifestando, assim, pelo menos em parte, sua sensibilidade em relação ao lugar destas crenças em sua rede de crenças coerentes. Mais, as crenças constituintes da perspectiva epistêmica de uma pessoa não são exceção. Guias de floresta, camponeses e marujos experientes acumulam muito saber que eles não podem formular simbolicamente. Depois de uma certa contemplação gestaltiana do ambiente ou de uma parte relevante dele, eles derivam certas inferências práticas apropriadas como, digamos, que uma tempestade está chegando, mesmo quando eles não são capazes de expressar simbolicamente o conhecimento que eles possuem, o conhecimento de que quando o mar e o céu têm tal e tal aparência, uma tempestade provavelmente vem chegando.

Esta passagem é reveladora da adesão sosiana aos postulados metaepistemológicos externalistas. Se concedemos que os velhos marujos estão justificados em suas crenças (além da mera posse de crença apta), mesmo que eles não sejam capazes de verbalizá-las, então eliminamos (ou pelo menos enfraquecemos demasiadamente) nosso compromisso com a tese da acessibilidade, algo inaceitável para um internalista. Sosa volta, pois, ao reino dos externalistas.

Uma interpretação possível do excerto seria aquela que considera que os marujos (por exemplo) têm acesso ao que justifica a crença (à evidência para aquilo que eles sustentam, por exemplo), mas padecem de outro mal, uma incapacidade de expressar os nexos entre evidência e conclusão. A menção de Sosa à "contemplação gestaltiana” enfraquece esta interpretação. Parece mesmo que Sosa defende que os sujeitos do excerto não padecem de mal algum, apenas devem seu conhecimento a virtudes que, como os processos confiáveis goldmanianos, são psicologicamente mais básicos e distintos da nossa reflexão. Mas isto enfraquece a noção de "conhecimento reflexivo". Precisaríamos distinguir entre aquele conhecimento reflexivo "não-proposicional" e o conhecimento reflexivo "proposicional", veiculável, passível de ensino e aprendizagem, que os humanos têm muito valorizado.

\subsubsection{Confiabilismo e perspectivismo das virtudes}

O ponto de contato entre o confiabilismo e a teoria sosiana é, como vimos, a teoria das virtudes intelectuais. Uma virtude intelectual, como vimos, incorpora um elemento de confiabilidade. O caráter conseqüencialista, que o próprio Goldman apontava como característico de seu confiabilismo, está implícito na noção sosiana de virtude intelectual (enquanto uma faculdade é virtuosa se tem, por conseqüência, a tendência para a verdade). A noção de virtude pode ser compreendida, como está claro, como uma modificação da noção de "processo confiável".

66 SOSA, Ernest. Virtue perspectivism: a response to Foley and Fumerton. p. 47. In. VILLANUEVA, Enrique (Ed.). Philosophical issues, 5 - Truth and rationality. Atascadero: Ridgeview, 1994. Em um ensaio posterior, Sosa sustenta que "Se uma faculdade opera para fornecer uma crença a um indivíduo e, daí, um pouco de conhecimento direto, o indivíduo deve possuir certa consciência [awareness] desta crença e de sua fonte, e da virtude da fonte tanto no geral quanto na instância específica" (SOSA, Emest. Three forms of virtue epistemology. In. AXTELL, Guy (Ed.) Knowledge, belief and character - Readings in virtue epistemology. Lanham: Rowman \& Littlefield, 2000, p. 38). Esta passagem - e eventuais outras semelhantes - poderia ser interpretada do mesmo modo. 
A teoria das virtudes intelectuais é, porém, apenas parte da teoria sosiana do conhecimento. Como vimos, as virtudes intelectuais estão todas subordinadas a uma virtude superior, uma virtude necessária para que o sujeito epistêmico atinja aquela perspectiva adequada em relação às suas crenças de primeira ordem e, assim, para que ele esteja justificado em crer no que crê (e, quiçá, para que atinja o conhecimento reflexivo). A teoria sosiana é, pois, uma teoria do perspectivismo das virtudes.

As vantagens devidas à inclusão da noção de coerência na teoria (como vimos, a coerência é requisito para a perspectiva adequada) não são pequenas. Enquanto detectamos adhocidades nas respostas goldmanianas para os problemas da MetaIncoerência e do Demônio Maligno, poupamos as respostas sosianas deste ataque. Isto porque, enquanto Goldman precisa fazer erguer - partindo do fundamento fornecido pelos processos cognitivos mais básicos - uma teoria da justificação ampla (que dê conta das crenças de primeira e de segunda ordem), Sosa pode se dar ao luxo de oferecer uma teoria da justificação e, paralelamente, uma outra teoria, da aptidão. Enquanto Goldman, devido aos compromissos meta-epistemológicos que assume, precisa construir um grande edifício, Sosa pode realizar a tarefa significativamente mais simples de erguer duas construções menores (a da justificação e a da aptidão), que se mantêm unidas pela noção de coerência.

Mas as semelhanças superam as diferenças. A apropriação da noção de virtude, pelo confiabilismo, será, como podemos esperar, muito pouco traumática. Como vimos, Sosa sugere que a noção de virtude intelectual é capaz de superar os impasses no debate coerentismo/fundacionismo. Podemos ver, agora, como a teoria sosiana articula as duas intuições: por um lado, a justificação depende da coerência interna do sujeito (como condição necessária para que o sujeito epistêmico atinja a perspectiva adequada em relação à crença), o que depende, como vimos, do uso de uma virtude de segunda ordem; por outro, a aptidão depende da existência das virtudes, que se organizam como um edifício, em que as virtudes de nível mais alto se apóiam nas virtudes mais básicas (lembrando que Goldman tomava a organização dos nossos processos e métodos de formação de crenças de modo semelhante).

\section{A Recepção goldmaniana da noção de virtude}

Antes de encerrarmos este ensaio, precisamos percorrer o caminho da recepção goldmaniana da noção de virtude nos moldes propostos por Ernest Sosa. Como vimos, a noção sosiana de virtude foi engendrada em íntima conexão com a noção de confiabilidade. Há, porém, pelo menos uma diferença significativa entre as suposições meta-epistemológicas das duas teorias: enquanto Goldman estabelece um critério para a classificação da confiabilidade de processos e métodos (o seu grau de confiabilidade), Sosa não assume tal compromisso. Por conta desse compromisso, Goldman acaba comprometido com um escalonamento dos processos e métodos de produção de crença em termos do seu grau de confiabilidade. Uma crença produzida por um processo mais confiável é, digamos, superior a uma crença produzida produzida por um processo mais abaixo na escala de confiabilidade. 
Vimos que Goldman enfrenta a questão da cancelabilidade com a cláusula (b) de (P3); vimos que, apesar da preocupação com a questão de o cancelamento da justificação ser uma questão essencial, a cláusula (b) parece não encontrar amparo no pressuposto meta-epistemológico que sustenta o escalonamento dos processos e métodos por conta de seu grau de confiabilidade assumido pelo confiabilista. O acréscimo da cláusula (b) parece ser, pois, como vimos, ad hoc.

A teoria sosiana escapa do problema. Para Sosa, aquela virtude de ordem superior que permite a posse de uma perspectiva adequada em relação à crença em questão é epistemologicamente superior. Se, numa dada situação, essa virtude indica a incoerência da crença em relação ao conjunto de crenças relacionadas à questão, então isto é suficiente para o decreto: a crença não pode estar justificada. Essa virtude superior tem sempre prioridade sobre as virtudes inferiores. Ou seja, enquanto Goldman monta apenas uma escala de avaliação, com os processos mais confiáveis no topo, Sosa monta duas: uma para as virtudes mais básicas e outra para as virtudes de ordem superior.

Estão claras, a esta altura, as vantagens da noção de 'virtude epistêmica' sobre a de 'processo confiável', e isso será reconhecido por Goldman, que incorporará ao confiabilismo uma teoria das virtudes intelectuais. Dadas as diferenças entre as teorias, devemos esperar uma recepção cuidadosa, por parte de Goldman, da noção de virtude nos termos sosianos. E é frustrante o modo pouco cuidadoso pelo qual, efetivamente, a incorporação da noção se dará.

A guinada do confiabilismo goldmaniano em direção a uma teoria das virtudes pode ser acompanhada no ensaio de 1992, Epistemic folkways and scientific epistemology. ${ }^{67}$ Neste ensaio, Goldman "pretende reformular e expandir sua própria concepção meta-epistemológica (articulada de modo mais completo em Epistemology and cognition), mantendo muitos dos seus elementos iniciais e, ao mesmo tempo, reconfigurando outros. A discussão não está, porém, de modo algum confinada ao nível meta-epistemológico. Novas propostas substanciais serão desenvolvidas e defendidas". ${ }^{68}$

No âmbito das questões meta-epistemológicas, a questão central do ensaio consiste em discutir o papel, na discussão epistemológica, dos nossos conceitos e princípios epistêmicos ordinários, os nossos epistemic folkways. Como seria de se esperar, dados os postulados meta-epistemológicos assumidos em 86, Goldman considera que é dever da epistemologia sempre partir da nossa epistemologia de senso comum mas, "mantendo a continuidade", sua segunda tarefa deve ser a de "reformar ou transcender" esta epistemologia ingênua. A primeira tarefa da epistemologia consiste em oferecer uma descrição dos conceitos epistemológicos vulgares. A segunda, na "formulação de um conjunto de normas epistêmicas mais adequado, sólido ou sistemático, um conjunto que de certo(s) modo(s) transcenda nosso

\footnotetext{
67 Que vem a ser o capítulo nono de GOLDMAN, Alvin. Liaison: Philosophy meets the cognitive and social sciences. Cambridge: The MIT Press, 1992.

Liaison, p. 155.
} 
repertório epistêmico vulgar". ${ }^{69}$ As duas tarefas, a descritiva e a normativa deverão ser realizadas com o auxílio das ciências cognitivas.

No âmbito da primeira tarefa, Goldman inclui a compreensão da noção de "justificação". Ele proporá, para tal, uma abordagem do conceito que

[...] participa da tradição confiabilista, mas se separa, num dado momento, de outras versões de confiabilismo. Minha abordagem tem a mesma idéia central da teoria das virtudes intelectuais de Ernest Sosa, mas incorpora alguns elementos distintos que potencializam seus resultados.

A tese básica consiste, grosso modo, em identificar o conceito de crença justificada com o conceito de crença obtida pelo exercício de virtudes (excelências) intelectuais. Crenças adquiridas (ou mantidas) através de uma cadeia de processos psicológicos "virtuosos" se qualificam como justificadas; aquelas adquiridas parcialmente através de "vícios" cognitivos são rebaixadas ao grupo das injustificadas [unjustified]. Esta é, como disse, a tese geral. Para explicá-la mais detalhadamente, eu preciso dizer algumas coisas sobre a psicologia do avaliador epistêmico, do possuidor e do detrator do conceito em questão [...].

A hipótese que eu gostaria de estabelecer é a de que o avaliador epistêmico tem um conjunto ou lista de virtudes e vícios cognitivos mentalmente armazenada. Quando convidado a avaliar um caso real ou hipotético de crença, o avaliador observa o processo pelo qual a crença foi produzida e o compara à lista de virtudes e vícios. Se o processo é composto apenas por virtudes, a crença é classificada como justificada. Se os processos são compostos parcialmente por vícios, a crença é categorizada como injustificada. Se um cenário de formação de crenças é descrito de modo tal que as características do processo não encontram correlação com a lista de virtudes e vícios, então a crença não pode ser classificada como justificada ou como injustificada, mas simplesmente como não-justificada [non-justified]. ${ }^{70}$

O primeiro parágrafo do excerto guiará nossa exegese da recepção goldmaniana da noção de virtude: com exceção daquilo que Goldman explicitamente mencionar, consideraremos como padrão a manutenção das suposições sosianas sobre a noção de virtude.

Os dois parágrafos seguintes marcam uma diferença significativa entre as preocupações goldmanianas e as sosianas: enquanto Sosa dedicou seus esforços à elaboração de uma definição formal de virtude epistêmica, Goldman considera necessário oferecer uma explicação substancial (conforme o espírito do programa explicitado no ensaio de 86) da noção de virtude, que será elaborada a partir das contribuições das ciências cognitivas. Cabe a elas, por exemplo, explicar como os indivíduos elaboram sua "lista interna de virtudes e vícios", como eles representam mentalmente as virtudes e vícios que subscrevem, como eles decidem que tais e tais casos são instâncias desta ou daquela virtude, etc. Melhor dizer, então, que a existência de virtudes intelectuais passa a ser uma hipótese a guiar nossas tentativas de descrição daquele aspecto da vida psicológica dos indivíduos comuns interessado na aquisição de verdades. ${ }^{71}$

Liaison, p. 156.

Liaison, p. 157.

Esta espécie de consideração não é nova, como vimos. Para ficar com apenas um exemplo, acompanhamos a tentativa goldmaniana de recurso a informações procedentes das Ciências Cognitivas para a dissolução do Problema da Generalidade. 
Esta tarefa descritiva da epistemologia subsidiará, por sua vez, o trabalho da epistemologia normativa. Tomemos, por exemplo, a questão, já discutida anteriormente, da culpabilidade do sujeito epistêmico. Quando, afinal, um indivíduo é culpável por haver falhado em crer algo que ele deveria crer?

Goldman sugere que, pelo menos em alguns casos em que intuitivamente reputamos o sujeito epistêmico como culpável, aparece envolvida aquela investigação sobre as próprias crenças do sujeito, envolvendo a memória. Vamos supor um caso em que um estudante de filosofia, às vésperas da colação de grau, redige seu discurso de formatura e comete uma falácia de negação do antecedente. Ele estudou lógica no longínquo começo de sua formação filosófica, e, dentre tantas novas informações, escutou seu professor bradando sobre o caráter falacioso da negação do antecedente. Dado o longo intervalo entre o início do curso e sua formatura, é o estudante culpável pelo erro ou se trata de um lapso não-culpável?

Goldman sugere que esta "é uma questão à qual os epistemólogos têm devotado pouca atenção, em parte porque pouco era conhecido sobre a recuperação de dados na memória até bem recentemente. Mas, agora que a ciência cognitiva tem ao menos um começo de compreensão deste fenômeno, a epistemologia normativa deve prestar cuidadosa atenção a esta pesquisa". ${ }^{72}$

Fica, aqui, ainda mais claro, o modo de incorporação da teoria sosiana por Goldman: como dissemos, a teoria sosiana das virtudes passa a ser, em primeiro lugar, uma hipótese a guiar a investigação das Ciências Cognitivas. E o que mais? Infelizmente, Goldman nada nos oferece em relação a esta questão. Não sabemos, por exemplo, se ele aceitará a superioridade daquela virtude que permite que o sujeito conhecedor perceba a coerência necessária para a posse de uma perspectiva adequada em relação às suas crenças. Não sabemos se a sugestão sosiana do abandono da idéia de escalonamento dos processos segundo sua confiabilidade será também incorporada. Como vimos, estas duas noções ocupam lugar central na teoria sosiana, além de serem incompativeis com pressupostos do confiabilismo goldmaniano. Mas Goldman não nos oferece a menor consideração sobre elas. Culpável por omissão!

\section{Referências}

ALMEIDA, Cláudio de. What Moore's paradox is about. Philosophy and Phenomenological research, 2001, vol. 62, n. 1, pp. 1-26.

AXTELL, Guy (Ed.). Knowledge, belief and character - Readings in virtue epistemology. Lanham: Rowman \& Littlefield, 2000.

BONJOUR, Laurence, externalist theories of empirical knowledge, In. FRENCH, P. (Ed.). Midwest Studies in Philosophy, v. 5: Studies in epistemology. Minneapolis: University of Minnesota Press, 1980 .

. Uma versão do deontologismo epistêmico. In. SOUZA, Draiton G. (Org.). Amor scientiae: festschrift em homenagem a Reinholdo Aloysio Ullmann. Porto Alegre: EDIPUCRS, 2002, pp. 12135.

DUTRA, Luiz H., Normatividade e investigação. Principia - Revista Internacional de Epistemologia, v. 1, n. 1, 1997, pp. 7-55.

72 Liaison, p. 171. 
FELDMAN, R. \& CONEE, E., Internalism defended. American Philosophical Quarterly, v. 38, n.1, Janeiro 2001, pp. 1 - 17

FELDMAN, Richard. Reliability and justification. The Monist, 68:2, 1985, 159-174.

FRENCH, UEHLING \& WETTSTEIN (Eds.). Midwest studies in Philosophy, v. 5: Studies in epistemology. Minneapolis: University of Minnesota Press, 1980.

FUMERTON, Richard. Sosa's epistemology. In. VILLANUEVA, Enrique (Ed.). Philosophical issues, 5 Truth and rationality. Atascadero: Ridgeview, 1994.

GOLDMAN, Alvin, A causal theory of knowing. The Journal of Philosophy, 64, 12, 1967, pp. 355-372.

. What is justified belief? In PAPPAS, G. S. (Ed.). Justification and knowledge. Dordrecht: D. Reidel, 1979, pp. 1- 24

. Epistemology and cognition. Cambridge: Harvard University Press, 1986.

- Strong and weak justification. In. TOMBERLIN, James (Ed.). Philosophical perspectives, 2, Epistemology, 1988. Atascadero: Ridgeview, 1988.

— Epistemic folkways and scientific epistemology. In. GOLDMAN, Alvin, Liaisons - Philosophy meets the cognitive and social sciences. Cambridge: The MIT Press, 1991. 1991.

LEHRER, K. \& COHEN, S., Justification, truth and coerence, Synthese, 55 (1983): 191-207.

LOCKE, John. Ensaio sobre o entendimento humano. Lisboa: Fundação Calouste Gulbenkian, 1999.

LUZ, Alexandre M. O que significa 'conhecer'? O problema de Gettier e três tentativas internalistas de solução. Dissertaç̃o: PUCRS, 1997.

PLATÃO. A República. São Paulo: Nova Cultural, 1997.

SOSA, Ernest. The raft and the pyramid: coherence versus foundations in the theory of knowledge. In. FRENCH, UEHLING \& WETTSTEIN (Eds.), Midwest studies in Philosophy - Volume V - Studies in epistemology. Minneapolis: University of Minnesota Press, 1980, pp. 3-25.

. Knowledge and intellectual virtue. The Monist, 68, 1985, pp. 224-45

. Knowledge in perspective: selected essays in epistemology. Cambridge: Cambridge University press, 1991

. Virtue perspectivism: a response to Foley and Fumerton. In. VILLANUEVA, Enrique (Ed.). Philosophical issues, 5 - truth and rationality. Atascadero: Ridgeview, 1994.

. Reflective knowledge in the best circles. The Journal of Philosophy, XCIV, n. 8, 1997.

. Three forms of virtue epistemology. In. AXTELL, Guy (Ed.) Knowledge, belief and character readings in virtue epistemology. Lanham: Rowman \& Littlefield, 2000, p. 38.

STEUP, Matthias. Knowledge, truth and duty - essays on epistemic justification, Responsibility, and Virtue. Oxford: Oxford UP, 2001.

TOMBERLIN, JAMES, Philosophical perspectives, 13 - Epistemology. Oxford: Blackwell Publishers, 1999.

VILLANUEVA, Enrique (Ed.). Philosophical issues, 5 - Truth and rationality. Atascadero: Ridgeview, 1994.

ZAGZEBSKI, Linda T. Virtues of the mind - an inquiry into the nature of virtue and the ethical foundations of knowledge. Cambridge: Cambridge University Press, 1996. 